\title{
FIRST RECORD OF ARGULUS JAPONICUS (CRUSTACEA: BRANCHIURA) ON CYPRINUS CARPIO IN NEPAL, WITH ADDITIONAL NOTES ON MORPHOLOGY AND PREVALENCE OF $A$. JAPONICUS AND ITS TREATMENT
}

\author{
A. Rayamajhi ${ }^{*}$, S. K.C. ${ }^{2}$, S. G.C. ${ }^{2}$, P. Kunwor ${ }^{1}$ \\ ${ }^{\mathbf{1}}$ Fisheries Research Division, Nepal Agricultural Research Council, Godawari, Lalitpur \\ ${ }^{2}$ SANN International College, Kathmandu \\ (*email:rayamajhiasha@hotmail.com)
}

\begin{abstract}
The present study recorded the parasite Argulus japonicus (Crustacea: Branchiura) as the first discovery in Nepal. The description was based on using 11 males (4.12 $\mathrm{mm}$ average TL) and 5 females (4.18 mm average TL) of Argulus japonicus which were collected from Godawari fish farm, Lalitpur. Biological behavior of one summer old common carp (Cyprinus carpio) infected with Argulus japonicuswere sluggish movement, jumping and poor growth grown in earthen pond in winter at water temperature $15.5{ }^{\circ} \mathrm{C}$ and $\mathrm{pH}$ 7.4. Heavily infected fishes showed brown-grey to reddish points throughout their body surface, especially on the caudal fins and on the body portion. Prevalence rate of this parasite was $80 \%$ in infected common carp fish with an average weight $261.80 \pm 85.12 \mathrm{~g}$ and length $22.9 \pm 4.9 \mathrm{~cm}$. Argulus mean intensity count was averaged 10.2 per infected fish with relatively high infestation in body surface (2.8 \pm 3.9$)$ followed by caudal fin

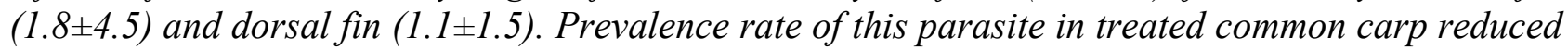
by $95 \%$ and Argulids assembled in several regions of the fish was in average 0.1/treated fish by feeding Duroclean treated feed. Duroclean, an aquaculture drug was found effective to control this parasite. The effective dose of the drug was $0.3 \mathrm{~g}$ per $\mathrm{kg}$ fish feed and fed for 3 days consecutively with one day off and then again for 2 days.
\end{abstract}

Keywords: Argulus japonicus, ectoparasite, prevalence rate, duroclean

\section{INTRODUCTION}

The family Argulidae contains a valid Genus Argulus Muller, 1785, more commonly known as fish louse cause argulosis disease. Species of the Argulus are found distributed throughout the world (Fryer, 1968; Post, 1987; Rushton-Mellor, 1992) and 143 species in the Genus have been described (Anon, 2001), although many of these species are synonymous (Taylor et al., 2005). Further Poly (2008) has enlisted about 129 valid species, occurs around all continents, except Antarctica, in marine and estuarine $(n=44)$ and freshwater habits $(n=85)$, in total, the diversity of freshwater Branchiura stands at 113 species. Among Crustacean parasite Argulus japonicus, Argulus foliaceus and Argulus coregoni arewidespread and the most documented species (Post, 1987; Taylor, et al., 2005).

In due course Argulosis disease is one of the major economic concerns in all phase of the aquaculture industry from production to marketing (Menezes et al., 1990; Taylor et al., 2006). Heavy infestations of Argulus parasite can induce significant morbidity and mortality in cultured fish population (Yamaguti 1963; Benz et al., 2001; Northcott et al., 1997; Wilson, 1902), both in 
carp (Rahman, 1996) and trout fish (Menezes et al., 1990). In Nepal ectoparasite Argulus are currently considered to be one of the most commercially pathogenic parasite and known to infect a wide variety of fish. Argulus was reported as threat to production of Rohu (Labeo rohita) and Naini (Cirrhinus mrigala) and breeding performance of cultured carp fish (Mandal and Prasad, 2011). Pantha (1998) has reported annual losses about 15-20\% loss in total fish production and 30-40\% loss in fish seed production due to various disease problems every year which accounts an economic loss of about Rs 1513.3 million per year in Nepal. Since the Argulus japonicus is the first record for Nepal, therefore current study has initiated to assess the infestation rate, undertaken the morphological study of the adult stage of Argulus japonicus including determine the promising drug against this parasite.

\section{MATERIALS AND METHODS}

A total of 20 Common carp(Cyprinus carpio) of average weight $261 \pm 80 \mathrm{~g}$ and length $22.9 \pm 4.9$ were collected from the earthen pond of Godawary fish farm, Lalitpur, at central Nepal for detection of Argulus infection in December 2015. Localities of fish farm at altitude N 27³5.989' and latitude E $085^{\circ} 23.246^{\prime}$ and 1576 masl elevation. Argulus were removed from head, body, fins and caudal fin of common carp using brush and forceps and Argulus number/fish was noted and fixed in $70 \%$ ethanol. Clinical examination of collected fish was adopted using the methods as described by Lucky (1977) for the determination of any lesions or abnormalities on the external body surface. Identification and morphological study of sampled parasite Argulus was according Bykhovskaya Pavlovskaya et al., (1962) and Rushton-Mellor (1994). Description of identified Argulus japonicus was based on studies of their 16 adult specimens (males $n=11$, females $n=5$ ) (Table 1). The measurement of total length (TL), total width (TW), carapace length (CL), carapace length as percent of total length, abdomen length (AL), abdomen length as percent of total length and abdomen width (AW) of Argulus japonicus was taken in millimeters under light olympus microscope. Photos of male and female Argulus japonicus, were also takenunder olympus microscope $(4 \mathrm{x})$ using digital camera. Sex determination was accomplished as mentioned by Wilson (1902). Prevalence, mean intensity and mean abundance were calculated as following the formula suggested by Margolis et al., (1982):

$\begin{array}{ll}\text { Prevalence }(\%)= & \frac{\text { Number of individual infected fish }}{\text { Total number of fish examined }} \times 100 \\ \text { Mean intensity }= & \frac{\text { Number of collected parasite }}{\text { Number of infected fish }} \\ \text { Abundance }= & \frac{\text { Number of parasite }}{\text { Number of fish examined }}\end{array}$

Efficacy of Duroclean (herbal extracts of satavari, copper salicylic acid, vitamin E and K) an aquaculture drug was tested on common carp as feed additive against Argulus parasite at research station: Godawary fish farm, Lalitpur district, Kathmandu. Further, drug verification trial was carried at farmer pond condition in Karaiya, Khaireni Nagarpalika-1, Chitwan central Nepal. 


\section{RESULTS}

The present study recorded the Argulus japonicus as the first representative of the genus isolated from the common carp fish. Argulus japonicus is recognizedby the abdomen lobes which have nearly rounded terminal end (slightly pointed than Argulus foliaceus); covered marginally with small spines and not covered by carapace. Furthermore, the posterior incisures of abdomen reaches middle of the body and pair of respiratory areas occurs on the ventral surface of lateral lobe of the carapace, the anterior respiratory area was smaller and roughly ovular in shape and posterior was much larger kidney bean shaped.

Body length of male Argulus japonicus4.12 \pm 0.46 (3.35-4.68) mm, body width $2.39 \pm 0.29$ (1.982.71) $\mathrm{mm}$ and abdomen length $1.03 \pm 0.10(0.90-1.15) \mathrm{mm}$, comprising $25.02 \pm 1.17(23.16-27.61) \%$ of total length; its posterior lobes tapering to relatively rounded points. Carapace length is $3.08 \pm 0.43(2.45-3.80) \mathrm{mm}$, comprising $74.62 \pm 3.40(69.80-81.28) \%$ of total length (Table 1). Cephalothoracic carapace extended beyond the beginning of abdomen and cover all four pairs of swimming legs (Fig. 1a, b). The males Argulus japonicus are more abundant than females (sex ratio $=68.8 \%$ ).

Table 1: Measurements of Argulus japonicus isolated from common carp

\begin{tabular}{llll}
\hline SN & Measurements $(\mathbf{m m})$ & Male $\mathbf{n = 1 1}$ & Female $\mathbf{n = 5}$ \\
\hline 1 & Total length (TL) & $4.12(3.35-4.68 \pm 0.46)$ & $4.18(3.58-4.75 \pm 0.46$ \\
2 & Total width (TW) & $2.39(1.98-2.71 \pm 0.29)$ & $2.35(2.11-2.50 \pm 0.16)$ \\
3 & Abdomen length (AL) & $1.03(0.90-1.15 \pm 0.10)$ & $0.93(0.78-1.05 \pm 0.11)$ \\
4 & AL as \% of TL & $25.02(23.16-27.61 \pm 1.17)$ & $22.35(21.28-23.33 \pm 0.86)$ \\
5 & Abdomen width (AW) & $0.60(0.41-0.80 \pm 0.11)$ & $0.56(0.45-0.66 \pm 0.09)$ \\
6 & Carapace length (CL) & $3.08(2.45-3.80 \pm 0.43)$ & $3.26(2.75-3.80 \pm 0.40)$ \\
7 & CL as \% of TL & $74.62(69.80-81.28 \pm 3.40)$ & $78.56(76.67-80.85 \pm 1.86)$ \\
\hline
\end{tabular}

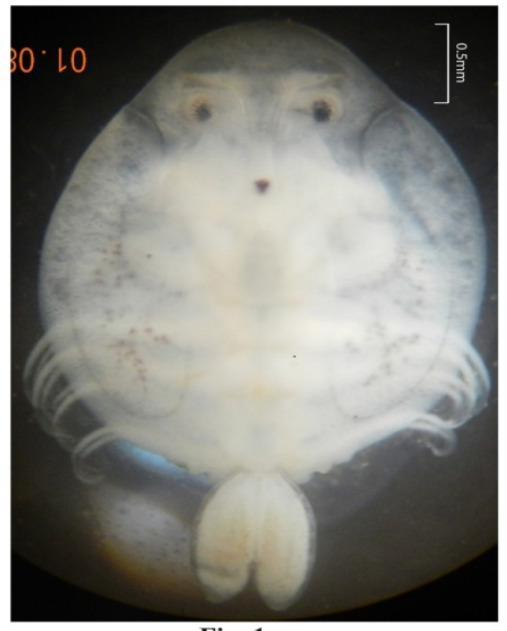

Fig. 1a

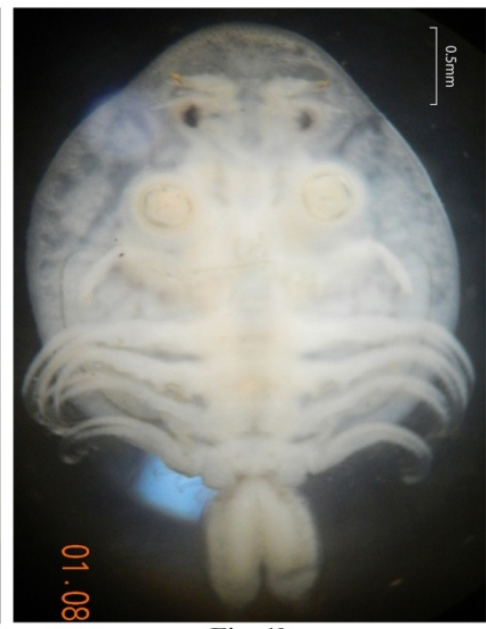

Fig. 1b

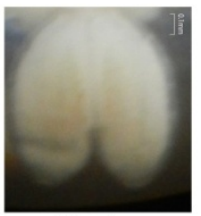

Fig. 1c

Fig. 1: Male of Argulus japonicus Thiele 1900 viewed under a light microscope (4x) (1a dorsal view, $1 \mathbf{b}$ ventral view; $1 \mathrm{c}$ abdomen with a pair of testis $(3.75 \mathrm{~mm} \mathrm{TL}, 0.90 \mathrm{~mm} \mathrm{AL}$ ) 
Body of female Argulus japonicus is slightly elongate, with length $4.18 \pm 0.46$ (3.58-4.75) mm and body width $2.35 \pm 0.16(2.11-2.50) \mathrm{mm}$. Abdomen length $0.93 \pm 0.11(0.78-1.05) \mathrm{mm}$, comprising $22.35 \pm 0.86(21.28-23.33) \%$ of total length; its posterior lobes tapering to relatively rounded points. Carapace length is $3.26 \pm 0.40(2.75-3.80) \mathrm{mm}$, comprising $78.56 \pm 1.86(76.67-80.85) \%$ of total length (Table 1). Cephalothoracic carapace extended beyond the beginning of abdomen and cover all four pairs of swimming legs (Fig. 2a, b).

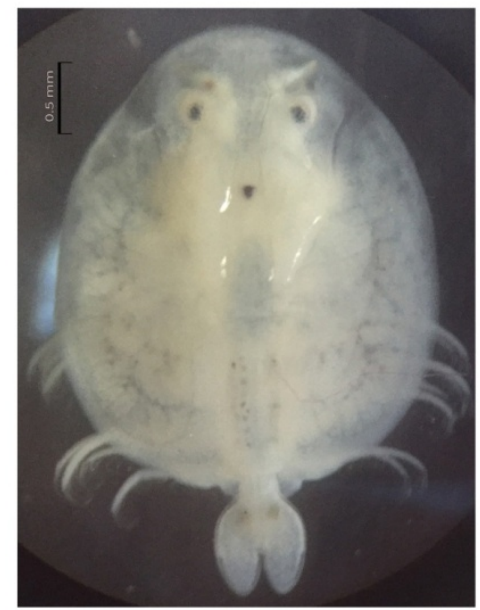

Fig. 2a

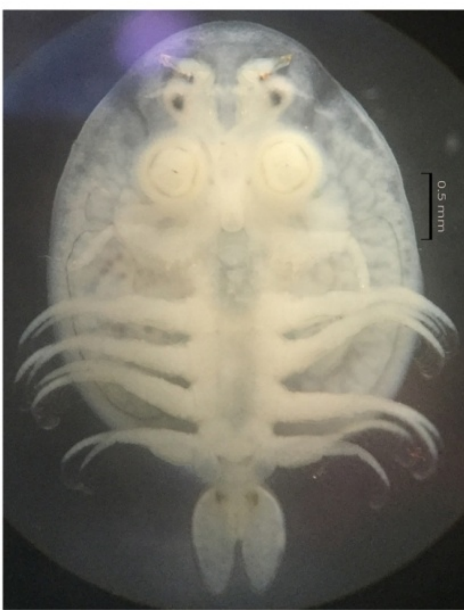

Fig. 2b

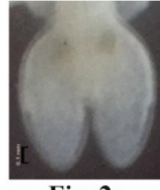

Fig. 2c

Fig. 2: Female of Argulus japonicus Thiele 1900 viewed under a light microscope (4x) (2a dorsal view; $2 \mathbf{b}$ ventral view; $2 \mathbf{c}$ abdomen with a pair of spermetogeneis (4.05 mm TL, $0.91 \mathrm{~mm} \mathrm{AL})$ )

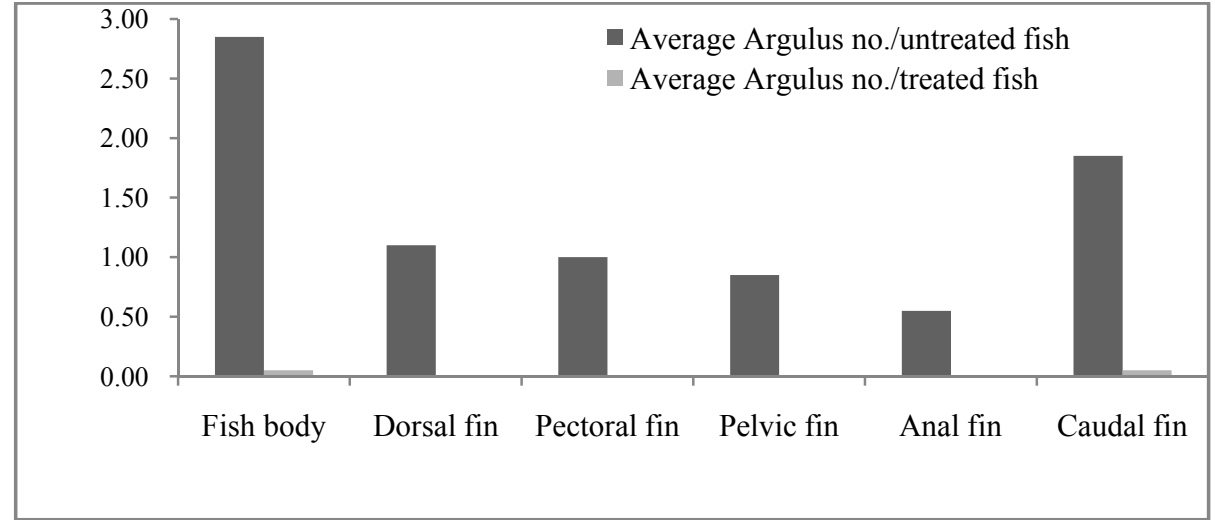

Fig. 3: Average Argulus no. assembled in body and fins of common carp before and after treatment

Specific difference between male and female of sampled Argulus japonicus included that the abdomen of the male contained the elongated a pair of testes, which were milky white with sperm in live specimens and dark in preserved specimens (Fig. 1a, b, c), while the abdomen of the female contained a pair of round spermathecae which was dark in color (Fig. 2a, b, c).

A total of 164 specimens of Argulus japonicus were isolated from one summer old common carp (Table 2). Prevalence rate of this parasite was $80 \%$ in infected fish. Argulids were assembled in several regions of the fish. Argulus mean intensity count was averaged 10.2 per infected fish with relatively high infestation on body surface (2.85 \pm 3.9$)$ followed by caudal fin $(1.85 \pm 4.5)$, dorsal fin

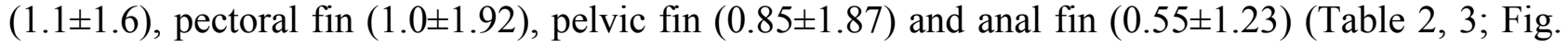


3). Fish infected with Argulus japonicus showed sluggish movements, jumping and poor growth in winter at water temperature $15.5^{\circ} \mathrm{C}$ and $\mathrm{pH} 7.4$.

Table 2: Individual number of Argulus parasiteattachedin different body parts of common carp fish, $\mathrm{n}=20$ in December 2015

\begin{tabular}{|l|l|l|l|l|l|l|l|l|l|}
\hline SN & $\begin{array}{l}\text { Total } \\
\text { weight of } \\
\text { Common } \\
\text { carp (g) }\end{array}$ & $\begin{array}{l}\text { Total } \\
\text { length of } \\
\text { common } \\
\text { carp } \\
\text { (cm) }\end{array}$ & $\begin{array}{l}\text { Argulus } \\
\text { counts } \\
\text { on body } \\
\text { surface }\end{array}$ & $\begin{array}{l}\text { Argulus } \\
\text { counts on } \\
\text { Dorsal } \\
\text { fin }\end{array}$ & $\begin{array}{l}\text { Argulus } \\
\text { counts on } \\
\text { Pectoral } \\
\text { fin }\end{array}$ & $\begin{array}{l}\text { Argulus } \\
\text { counts } \\
\text { on Pelvic } \\
\text { fin }\end{array}$ & $\begin{array}{l}\text { Argulus } \\
\text { counts } \\
\text { Anal fin }\end{array}$ & $\begin{array}{l}\text { Argulus } \\
\text { counts } \\
\text { on } \\
\text { Caudal } \\
\text { fin }\end{array}$ & $\begin{array}{l}\text { Total } \\
\text { Argulus } \\
\text { no/infected } \\
\text { fish }\end{array}$ \\
\hline 1 & 470 & 29.1 & 4 & 0 & 8 & 7 & 3 & 2 & 24 \\
\hline 2 & 190 & 23.8 & 2 & 1 & 3 & 5 & 3 & 2 & 16 \\
\hline 3 & 280 & 25.5 & 0 & 0 & 0 & 0 & 0 & 0 & 0 \\
\hline 4 & 302 & 25.9 & 5 & 5 & 0 & 0 & 0 & 20 & 30 \\
\hline 5 & 268 & 26.1 & 18 & 2 & 3 & 1 & 1 & 2 & 27 \\
\hline 6 & 360 & 29.5 & 5 & 3 & 1 & 0 & 4 & 6 & 19 \\
\hline 7 & 266 & 26.2 & 1 & 0 & 0 & 0 & 0 & 0 & 1 \\
\hline 8 & 380 & 11.8 & 1 & 0 & 0 & 0 & 0 & 0 & 1 \\
\hline 9 & 172 & 21.2 & 0 & 0 & 0 & 0 & 0 & 0 & 0 \\
\hline 10 & 168 & 26.3 & 1 & 0 & 0 & 0 & 0 & 0 & 1 \\
\hline 11 & 150 & 19.5 & 0 & 0 & 0 & 0 & 0 & 0 & 0 \\
\hline 12 & 262 & 23.6 & 1 & 2 & 0 & 0 & 0 & 0 & 3 \\
\hline 13 & 325 & 10.4 & 2 & 0 & 1 & 2 & 0 & 0 & 5 \\
\hline 14 & 260 & 25 & 4 & 0 & 0 & 0 & 0 & 2 & 6 \\
\hline 15 & 142 & 19.1 & 0 & 0 & 0 & 0 & 0 & 0 & 0 \\
\hline 16 & 295 & 25.1 & 2 & 0 & 1 & 0 & 0 & 0 & 3 \\
\hline 17 & 248 & 22.1 & 3 & 1 & 2 & 0 & 0 & 0 & 6 \\
\hline 18 & 250 & 23.1 & 3 & 4 & 1 & 0 & 0 & 1 & 9 \\
\hline 19 & 148 & 20.5 & 2 & 3 & 0 & 1 & 0 & 1 & 7 \\
\hline 20 & 300 & 25.2 & 3 & 1 & 0 & 1 & 0 & 1 & 6 \\
\hline Total & 20 & & 57 & 22 & 20 & 17 & 11 & 37 & 164 \\
\hline Av & 261.80 & 22.95 & 2.85 & 1.1 & 1.0 & 0.85 & 0.55 & 1.85 & 8.2 \\
\hline SD & 85.12 & 4.93 & 3.91 & 1.55 & 1.92 & 1.87 & 1.23 & 4.51 & 9.63 \\
\hline
\end{tabular}

Table 3: Infestations value of Argulus parasite on the common carp fish

\begin{tabular}{llllllll}
\hline Season & $\begin{array}{l}\text { No. of } \\
\text { fish } \\
\text { examined }\end{array}$ & $\begin{array}{l}\text { No. of fish } \\
\text { infected }\end{array}$ & $\begin{array}{l}\text { No. } \\
\text { collected } \\
\text { parasites }\end{array}$ & of & $\begin{array}{l}\text { Prevalence } \\
\%\end{array}$ & $\begin{array}{l}\text { Mean } \\
\text { Intensity }\end{array}$ & Abundance \\
\hline Winter & 20 & 16 & 164 & 80 & 10.25 & 8.2 \\
\hline
\end{tabular}

Besides, heavily infected fishes had some clinical symptoms as brown-grey to reddish points throughout their body surface, especially on the caudal fins and on the body portion. As a control measure, Duroclean was found effective against this parasite. Prevalence rate of this parasite in common carp reduced by $95 \%$ and Argulids were assembled in several regions of the fish that was 0.1/treated fish by feeding Duroclean treated feed. Although assembled argulids was 8.2/infected 
fish (Table 2, 3; Fig. 3). The effective dose of the drug was $0.3 \mathrm{~g}$ per $\mathrm{kg}$ fish feed and fed for 3 days consecutively with one day off and then again for 2 days.

\section{DISCUSSION}

Argulus japonicus was originally described by Thiele (1900) locality from China and further discovered in Europe, North America, Australia and Africa (Taylor et al., 2005). Poly (2008), mentioned that Argulus japonicus Thiele, 1900 has been introduced from east/southeast Asia to all other continents, except Antarctica as well as currently discovered from central Nepal. Argulus japonicus has been studied by several authors such as Ikuta and Makioka (1997a) (described the structure of adult ovary and oogenesis); Gresty, et al., (1993) (described the structure and function of cephalic appendages); Tokioka (1936) and Lutsch and Avenant-Oldewage (1995) (described the larval stages); Tam (2005) (elucidate the pathogenecity of Argulus japonicus); Avenant $\square$ Oldewage and Swanepoel (1993) (described the male reproductive system and mechanism of sperm transfer) and Ikuta et al. (1997b) (described the eggshell in Argulus japonicus). Rushton-Mellor (1994) described the shape of respiratory areas and abdomen as species specific of Genus Argulus. Additionally, Rushton-Mellor (1994) has mentioned the carapace lobes covers the all four pairs of swimming legs particularly in Argulus japonicus.

During current study, the morphometric comparison of collected Argulus japonicus was made with its closely related congeners; Argulus coregoni and Argulus foliaceus. The specimens of Argulus japonicus are distinguished with Argulus coregoni (Thorell 1866) by nearly rounded abdomen lobes (vs. sharply pointed abdomen lobes), by posterior lobes of cephalothoracic carapace extended beyond the beginning of abdomen (vs. posterior lobes of cephalothoracic carapace not extended beyond the beginning of abdomen), by the posterior incisures of abdomen reaching the mid-line (vs. posterior incisures of abdomen reach beyond middle of the abdomen) and by the body length 3.35$4.75 \mathrm{~mm}$ (vs. $12 \mathrm{~mm}$ body length) (Yildiz andKumantas, 2002; Saha and Bandyopadhyay, 2015). Argulus japonicus distinct with Argulus foliaceus (Linne, 1758), by nearly rounded abdomen lobes (vs. rounded lobes of abdomen), by the posterior incisures of abdomen reaching the mid-line (vs. the posterior incisures not reaching the mid-line), by posterior lobes of cephalothoracic carapace extended beyond the beginning of abdomen (vs. posterior lobes of cephalothoracic carapace not extended beyond the beginning of abdomen) (Yildiz and Kumantas, 2002; Saha and Bandyopadhyay, 2015).

Argulus japonicus is an opportunist parasite (Shafir and Oldewage, 1992; Avenant-Oldewage, 2001). Infestation with this parasite can reach severe proportions in a very short time which result in catastrophic fish deaths (Menezes et al., 1990; Northcott et al., 1997; Avenant-Oldewage 2001; Taylor et al., 2006). Bower-Shore, 1940; Shimura et al., 1983; Ahne, 1985; Moravec, 1994 and Bandilla et al., 2006 has mentioned that Argulus causes increase the susceptibility of secondary infections to its host. Against Argulus parasite, several chemicals such as salt $(\mathrm{NaCl})$ (Singhal et al., 1986), formaldehyde (Rydlo, 1989), potassium permanganate (Singhal et al., 1986; Jafri and Ahmed, 1994), quicklime (Jafri and Ahmed, 1994; Ahmed, 2004), organophosphorus (Chandra et al., 2004) and Gammexane (Singhal et al., 1986) have been found applied in aquaculture industry. In the current study efficacy of Duroclean was found promising to minimize Argulus number/infected fish (Argulus reduced from 8.2 to 0.1 / infected fish). Studies are warned to identify 
the interaction between environmental conditions and outbreak of Argulus japonicus for developing better management practices of carp aquaculture.

\section{ACKNOWLEDGEMENT}

This work was funded by Nepal Agricultural Research Council (NARC) under Project No: 32068005. The Authors wish to thank farmer of Karaiya, Khaireni Nagarpalika-1, Chitwan for their help to carry out the drug verification study.

\section{REFERENCES}

Ahmed, A.T.A. (2004). Development of environment friendly measures for the treatment of argulosis in carp brood pond. Bangladesh Journal Fish, 27: 3.

Ahne, W. (1985). Argulus foliaceus L. and Piscicola geometra L. as mechanical vectors of spring viraemia of carp virus (SVCV). Journal of fish diseases, 8(2): 241-242.

Anon., (2001). The World of Copepods; Copepod Species Taxonomy Result. National Museum of Natural History-Department of Invertebrate Zoology. http://www.nmnh.si.edu/cgi$\mathrm{bin} / \mathrm{wdb} /$ cope/cope_taxa/query.

Avenant-Oldewage, A. (2001). Argulus japonicus in the Olifants River System-possible conservation threat? South African Journal of Wildlife Research,31(1-2): 59-63.

Avenant-Oldewage, A. and Swanepoel, J.H. (1993). The male reproductive system and mechanism of sperm transfer in Argulus japonicus (Crustacea: Branchiura). Journal of morphology,215(1): 51-63.

Bandilla, M., Valtonen, E.T., Suomaleinen, L.R., Aphalo, P.J. and Hakalahti, T. (2006). A link between ectoparasite infection and susceptibility to bacterial disease in rainbow trout. International Journal for Parasitology,36: 987- 991.

Benz, G.W., Bullard, S.A. and Dove, A.D.M. (2001). Metazoon parasites of fishes: synoptic information and portal to the literature for aquarists. Regional Conf Proc, anon (ed) Am Zoo Aquar Assoc, Silver Spring.

Bower-Shore, C. (1940). An investigation of the common fish louse, Argulus foliaceus (Linn.) Parasitology,32: 361-371.

Bykhovskaya-Pavlovskaya, I.E., Gusev, A.V., Dubinina, M.N., Izyumova, N.A., Smirova, T.S., Sokolovskaya, I.L., Shtein, G.A., Shulman, S.S. and Epshtein, V.H. (1962). Key to Parasites Freshwater Fishes of the U.S.S.R. (Translated from Russian, Editor Pavlovskii EEN, Israel Program for Scientific Translations, Jerusalem, 1-919.

Chandra, K.J., Das, A.K., Alim, M.A., and Barai, A.K. (2004). Lice (Argulus foliaces) on carp of Bangladesh Agricultural University experimental pond. The Bangladesh Veterinarian,21(1): 66-69.

Fryer, G. (1968). The parasitic Crustacea of African freshwater fishes; their biology and distribution. Journal of Zoology,156: 45-95.

Gresty, K.A., Boxshall, G.A. and Nagasawa, K. (1993). The fine structure and function of the cephalic appendages of the branchiuran parasite, Argulus japonicus Thiele. Philosophical Transactions of the Royal Society B: Biological Sciences, 339(1287): 119-135.

Ikuta, K. and Makioka, T. (1997a). Structure of the adult ovary and oogenesis in Argulus japonicus Thiele (Crustacea: Branchiura). Journal of Morphology, 231(1): 29-39. 
Ikuta, K., Makioka, T. and Amikura, R. (1997b). Eggshell ultrastructure in Argulus japonicus (Branchiura). Journal of Crustacean Biology, 17(1), 45-51.

Jafri, S.I.H. and Ahmed, S.S. (1994). Some observations on mortality in major carps due to fish lice and their chemical control. Pakistan Journal of Zoology, 26(3): 274-276.

Lucky, Z. (1977). Methods for the diagnosis of fish diseases Amerial Publication Co. Pvt, Ltd, New Delhi and New York.

Lutsch, E. and Avenant-Oldewage, A. (1995). The ultrastructure of the newly hatched Argulus japonicus Thiele, 1900 larvae (Branchiura). Crustaceana,68(3): 329-340.

Mandal, J.K. and Prasad, B. (2011). Status of Fish Disease Problem and Associated Economic Loss in Nepal. Proceedings of the 8th National Workshop on Livestock and Fisheries Research, Nepal Agricultural Research Council (NARC), 78-82 pp.

Margolis, L., Esch, G.W., Holmes, J.C. and Schod, G.A. (1982). The use of ecological terms in parasitology. Report of an ad-hoc Committee of the American Society of Parasitologists. Journal Parasit. 68:131-133.

Menezes, J., Ramos, M.A., Pereira, T.G. and Moreira, da Silva A. (1990). Rainbow trout culture failure in a small lake as result of massive parasitosis related to careless fish introduction. Aquaculture,89:123-126.

Moravec, F. (1994). Parasitic Nematodes of Freshwater Fishes of Europe. Prague: Academia.

Northcott, S.J., Lyndon, A.R. and Campbell, A.D. (1997). An outbreak of freshwater fish lice, Argulus foliaceus L., seriously affecting a Scottish Stillwater fishery. Fisheries Management and Ecology, 4:73-75.

Pantha, M.B. (1998). National status and strategy for quarantine and health certification for responsible movement of live aquatic animals-A Country Report of Nepal. Feb 1-5, 1998, Bangkok.

Poly, W.J. (2008). Global diversity of fishlice (Crustacea: Branchiura: Argulidae) in freshwater. Hydrobiologia,595(1): 209-212.

Post, G. (1987). Textbook of Fish Health. T.F.H Publications, Canada.

Rahman, M. (1996). Effects of a freshwater fish parasite, Argulus foliaceus Linn. Infection on common carp, Cyprinus carpio Linn. Bangl. Journal Zool.24(1): 57-63.

Rushton-Mellor, S.K. (1992). Discovery of the fish louse, Argulus japonicus Thiele (Crustacea: Branchiura), in Britain. Aquaculture Research,23(2): 269-271.

Rushton-Mellor, S.K. (1994). The genus Argulus (Crustacea: Branchiura) in Africa: identification keys. Systematic Parasitology,28(1): 51-63.

Rydlo, M. (1989). Comparative experiments on the control of some fish ectoparasitoses. Current trends in fish therapy. Proceedings of a joint WAVSFD and DVG meeting held in Munich on 25-26 April; 1989; 76-90.

Saha, M. and Bandyopadhyay, P.K. (2015). First report of three species of Argulus (Crustacea: Branchiura) infesting on red can Oranda goldfish (Carassius auratus auratus) in India. Biolife an International Quarterly Journal of Biology and Life Sciences,3(4): 813-819.

Shafir, A. and Oldewage, W. H. (1992). Dynamics of a fish ectoparasite population: opportunistic parasitism in Argulus japonicus (Branchiura). Crustaceana,62(1):50-64.

Shimura, S., Inoue, K., Kudo, M. and Egusa, S. (1983). Studies on the effects of parasitism of Argulus coregoni (Crustacea: Branchiura) on Furunculosis of Onchorynchus masou (Salmonidae). Fish Pathology, 18(1): 37-40.

Singhal, R.N., Jeet, S. and Davies, R.W. (1986). Chemotherapy of six ectoparasitic diseases of cultured fish. Aquaculture,54(3), 165-171. 
Tam, Q. (2005). Aspects of the biology of Argulus. MSc. Thesis. University of Johannesburg. 104p. Taylor, N.G.H, Sommerville, C. and Wootten, R. (2005). A review of Argulus spp. occurring in UK freshwaterrs. Science Report SC990019/SR1, Published by Environment Agency, Rio House, Waterside Drive, Aztec West, Almondsbury, Bristol, BS32 4UD, 1-30

Taylor, N.G.H, Sommerville, C. and Wootten, R. (2006). The epidemiology of Argulus spp. (Crustacea: Branchiura) intentions in Stillwater trout fisheries. Journal of Fish Diseases, 29: 193-200.

Thiele, J. (1900). Diagnoses neuer Arguliden-Arten. - Zoologischer Anzeiger 23: 46-48.

Tokioka, T. (1936). Preliminary report on Argulidae found in Japan. Annotationes Zoologicae Japonenses, 15(3): 334-341.

Wilson, C.B. (1902). North American parasitic copepods of the family Argulidae: With a bibliography of the group and a systematic review of all known species. Proceedings of the United States Natural Museum, 25 (1302): 635-762

Yamaguti, S. (1963). Parasitic Copepoda and Branchiuran of fishes, Interscience Publs, New York.

Yildiz, K. and Kumantas, A. (2002). Argulus foliaceus infection in a goldfish (Carassius auratus). Israel Journal of Veterinary Medicine, 57(3): 118-120. 